\title{
Evaluation of the Performances of the First Grid-Connected Photovoltaic System in Sénégal
}

\author{
P. W. Tavares ${ }^{1,2}$, H. D. Ndiath ${ }^{1,2}$, M. Kâne ${ }^{1,2}$, B. Mbow ${ }^{1}$, A. T. Niang², I. Youm ${ }^{1,2}$ \\ ${ }^{1}$ Laboratoire des Semi-Conducteurs et d'Energie Solaire (LASES) Département de Physique, Faculté des Sciences et Techniques, \\ Université Cheikh Anta Diop de Dakar, Sénégal \\ ${ }^{2}$ Centre d'Etudes et de Recherches sur les Energies Renouvelable (CERER) BP 476 Dakar, Université Cheikh Anta Diop, Dakar, \\ Sénégal \\ Email: pierrewilliams.tavares@ucad.edu.sn
}

How to cite this paper: Tavares, P.W. Ndiath, H.D., Kâne, M., Mbow, B., Niang, A.T. and Youm, I. (2020) Evaluation of the Performances of the First Grid-Connected Photovoltaic System in Sénégal. International Journal of Clean Coal and Energy, 9, 1-14.

https://doi.org/10.4236/ijcce.2020.91001

Received: May 13, 2019

Accepted: February 25, 2020

Published: February 28, 2020

Copyright (c) 2020 by author(s) and Scientific Research Publishing Inc. This work is licensed under the Creative Commons Attribution International License (CC BY 4.0).

http://creativecommons.org/licenses/by/4.0/

\begin{abstract}
This document presents the evaluation and the monitoring of the performances of the first grid-connected photovoltaic system installed in the Center of Studies and Researches on the Renewable Energies (CERER) inaugurated on December $4^{\text {th }}, 2012$ by the governmental authorities of Senegal and Tenerife. This mini power plant of $3.15 \mathrm{kWc}$ is a perfect example of the political will of the government which is to reduce the production cost of the electricity, with the diversification of the sources of production, and the greater use of the other sources such as the natural gas, the coal, the renewable energies. The evaluation of the performances of the installation is realized by using the indicators of efficiency and performance as the photovoltaic surface yield, the ratio of photovoltaic performance, the photovoltaic specific yield, and the losses of captures. The obtained results show that a big part of the energy shone during the period of observation was not able to be used further to circumstances such as the losses of conductivity, the heat losses or for example the defects on components. The analysis also shows that a large part of the produced energy is not injected because of the dilapidation of the network, the defects of landing but especially one disjunction sees frequently at the level of the point of injection.
\end{abstract}

\section{Keywords}

Analysis of the Performances, The Photovoltaic Solar Energy, Grid-Connected PV System, Senegal

\section{Introduction}

Throughout the history of PV development, the dominant application of PV 
systems has been the stand-alone ones. In a stand-alone PV system, a PV array is the only source of energy powering all the electrical loads [1]. However, the increasing concern concerning the demand in electricity, the global warming and the reduction in the cost of the photovoltaic modules became engines for bigger photovoltaic applications. The cumulative global photovoltaic (PV) capacity has been growing exponentially latest years around the world, especially due to the installation of grid connected PV systems. This growth indicates that PV energy production will have a very important role in the total generation of electricity of the future [2].

The energy coming from the sun received every year in Senegal is of the order of 394 thousand billion $\mathrm{kWh}$ what amounts to 33,830,000,000 TEP (Equivalent Tons Oil). The solar energy is one of the energy solutions adopted by Senegal to diversify his sources of power production as well as to promote the development of this renewable source of energy.

Many studies were realized within the framework of the evaluation and the monitoring of the grid-connected PV systems. Aristizàbal et al. [3] controlled for two years the performance monitoring results of the first grid-connected BIPV system in Colombia and found when the power PV produced by the building fills the exercise books of loads required for this system by the national and international standards. During ten years, Hoz et al. [4] examined the various actions made to promote the system connected to the distribution network. About the stability of the network, Lam et al. [1] presented an approach to model PV systems, thing important for the technologies in fast development and the integrated sources. They also made a case study in a school in Hong-Kong Mawan in diverse conditions and the prediction of the dynamic model expresses itself precise. Some go farther as Jannuzzi et al. [5] who go as far as studying the impact which will have these systems connected to the network in the future. Sidi et al. [6] estimated the performances of the first installation PV connected to the large-scale network in Mauritania (15 MWp) and compared it with other systems installed in other countries. They found that the environmental conditions play on the performances of the installation.

In the current electric system in Senegal, bordering country with Mauritania, company which distributes the electricity produces the energy from the levels of high voltages and distributes it to networks of lower levels of tension. To assure a safer and more environment-friendly energy supply and to reduce the energy dependence of the country towards the not renewable energies, the government of Senegal set up an energy policy favouring the development of the renewable energies [7] [8].

The photovoltaic experimental system injected in the network of the SENELEC installed in the Center of Studies and Researches on the Renewable energies (CERER) is a perfect example of development of the photovoltaic solar energy in Senegal among which one of the biggest utilities is to serve as bench of test in various operational conditions of the SENELEC network (electric distribution 
network). This installation was born within the framework of the project MACSEN-PV "Study of the alternatives for the electric supply from the renewable sources of energy in Tenerife and in Senegal, technology transfer and pilot project of installation of a system connected to the network", which was financed by the European program of transnational cooperation MAC 2007-2013 (Cooperation with third countries).This PV system connected to the network is the first to be installed in Senegal. This system made it possible to assess the impact of an injection on the distribution network because the national network is outdated, the injection conditions are not always favourable with frequency and voltage reductions. It is a pilot system whose results have enabled the SENELEC to renovate its electricity network but also to start diversifying its production by accepting systems connected to the network but always very cautiously.

The evaluation and the monitoring of the performances of this system PV connected to the network are necessary to judge the state of progress of this experimental system and detect possible defects or errors bound to the system or to the network of food or even to the environment to draw beneficial conclusions for its penetration in the households there.

\section{Site of the Installation}

The photovoltaic system connected to the network is a pilot-plant of $3.15 \mathrm{kWc}$ injected in the national network of Senegal. It is installed in the Center of Studies and Researches on the Renewable Energies (CERER), an institute of the University Cheikh Anta Diop of Dakar (UCAD) creates in 1980 to lead activities of research in all the specialties of the technologies of renewable energies (PV, wind turbine, biomass, and thermal solar energy).As shown in Figure 1, the geographical address and coordinates of the site of installation are:

- Latitude: $14^{\circ} 43^{\prime} 10^{\prime \prime}$ North

- Longitude: $17^{\circ} 26^{\prime} 24^{\prime \prime}$ West

- Leigh: $35 \mathrm{~m}$

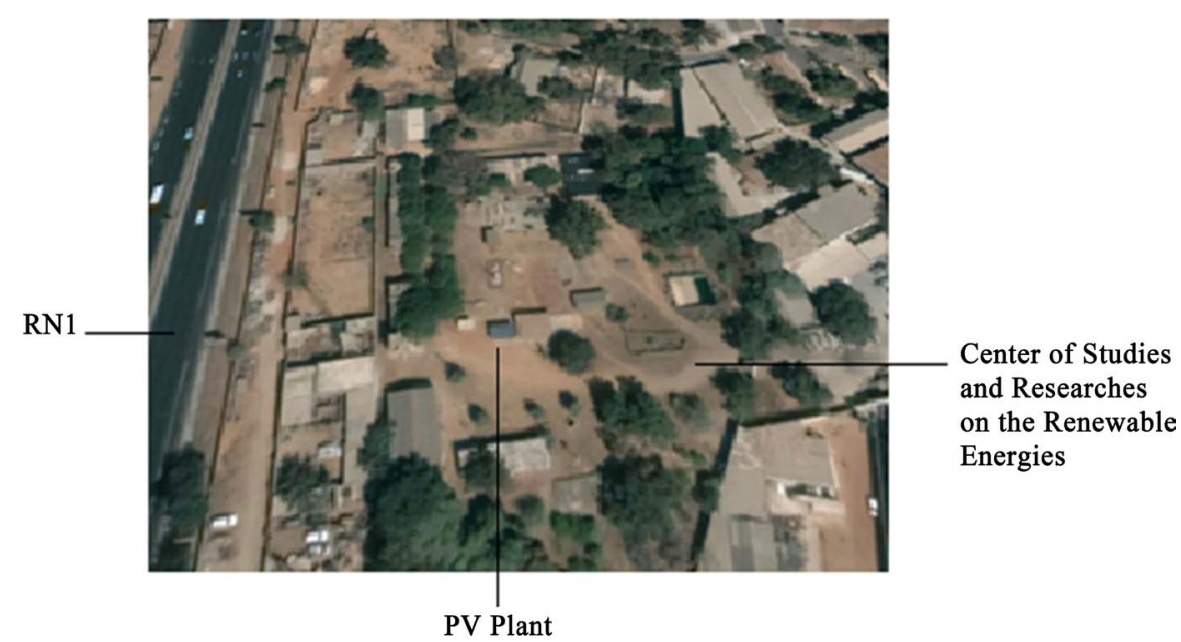

Figure 1. MACSEN-PV project localization site (picture: Google earth). 
The installation, inaugurated on December $4^{\text {th }}, 2012$ by the governmental authorities of Senegal and Tenerife, was finally connected to the Senegalese public network on April $26^{\text {th }}, 2013$.

\section{Design of the System}

This experimental system is a photovoltaic system linked with the network with functioning of reassurance and includes a meter of injection for the production and a meter of acquisition for the consumption. This experimental system connected to the network allows not only to inject totally and directly in the network the energy produced if this one presents corresponding characteristics, but also to be able to work in an autonomous way when the network breaks down. It becomes a backup system. It contains 18 photovoltaic modules type polycrystalline gone up in series with a power of $3.15 \mathrm{kWc}$. Modules rose at ground level on facing south surfaces tilted to an angle of $10^{\circ}$. They were arranged to constitute a parking lot of car park. The direct current stemming from panels is transformed into alternating current by the inverter SB $3000 \mathrm{TL}$ which injects it in the network through a meter of injection. The network provides power through the acquisition counter. This current powers large electrical appliances, emergency charges and recharges the battery. In case of breakdown of the network (total absence or electric quality of the exceptional network), it disconnects through the automatic disconnect point and feeds the rescued loads. This disconnect point makes it possible not to inject production when the power grid is not up to standard so as not to lose production. This experimental system also contains differential protections $(300 \mathrm{~mA})$ and magnetostatic protections against the returns of current and the lightning. The low power of the system makes impossible a surge and three magnétothermal $(30 \mathrm{~A})$ protections assure the protection against the short circuit and against the overloads as shown in Figure 2.

\section{Components of the System}

The components of the system were detailed in Table 1. It is essentially about modules used for the power plant, about inverters of injection and about backup, about batteries of accumulations necessary for the storage of the produced and not injected energy and the systems of control which allow us to control the power plant.

\section{Functioning of the System}

The system is in single-phase regime. The injection of the system experimental of $3.15 \mathrm{kWc}$ in the network is made on a range of frequency between $47.65 \mathrm{~Hz}$ and $50.5 \mathrm{~Hz}$ and a range of tension between $187 \mathrm{~V}$ and $261.5 \mathrm{~V}$. If the frequency and the tension are situated in this range, the system injects in the network and feeds the big devices (helped load and not helped loads) by the inverter SB 3000 $\mathrm{TL}$ which has a power of $3000 \mathrm{~W}$. This power of $3000 \mathrm{~W}$ transforms the current DC/AC. When the frequency and the tension are situated outside the range or 
Table 1. Components of the pilot-system.

\begin{tabular}{|c|c|}
\hline \multicolumn{2}{|c|}{ Components of the system. } \\
\hline The photovoltaic modules & \\
\hline Unitarian power & $175 \mathrm{Wc}$ \\
\hline Type of modules & Polycrystalline silicon \\
\hline Model & ST175 P-1 \\
\hline Size & $1306 * 991 * 40 \mathrm{mms}$ \\
\hline Surface of the panel & $1.92 \mathrm{~m}^{2}$ \\
\hline Number of panels & 18 \\
\hline Tension to Pmax (Vmpp) & $23.1 \mathrm{~V}$ \\
\hline Intensity to Pmax (Impp) & $7.55 \mathrm{~A}$ \\
\hline Intensity of short circuit (Isc) & $8.19 \mathrm{~A}$ \\
\hline Tension of opened circuit (Vco) & $29.5 \mathrm{~V}$ \\
\hline \multicolumn{2}{|l|}{ Inverters } \\
\hline \multicolumn{2}{|l|}{ The inverter of injection SB $3000 \mathrm{TL}$} \\
\hline Manufacturer & SMA \\
\hline Model & Sunny Boy 3000 TL \\
\hline Maximal power & $3200 \mathrm{KW}$ \\
\hline Range of tension MPP & $188 \mathrm{~V}-440 \mathrm{~V}$ \\
\hline Current DC & $17 \mathrm{~A}$ \\
\hline Range of tension AC & $180 \mathrm{~V}-280 \mathrm{~V}$ \\
\hline Current AC & $16 \mathrm{~A}$ \\
\hline Memory of data & SD card, 2 Gb max \\
\hline \multicolumn{2}{|l|}{ The inverter of help SBU } \\
\hline Manufacturer & SMA \\
\hline Model & Sunny Backup on 2200 \\
\hline Rated output (network mode) & $5.7 \mathrm{KW}$ \\
\hline Power of support (continuous/30min/1min) & $2.2 \mathrm{KW} / 2.9 \mathrm{KW} / 3.8 \mathrm{KW}$ \\
\hline Tension & $230 \mathrm{~V}(172.5 \mathrm{~V}-264.5 \mathrm{~V})$ \\
\hline Frequency & $50 \mathrm{~Hz}(45 \mathrm{~Hz}-65 \mathrm{~Hz})$ \\
\hline Time of interruption in case of cut of the network & $50 \mathrm{~ms}$ \\
\hline Nominal tension of the bench of batteries & $24 \mathrm{~V}$ \\
\hline \multicolumn{2}{|l|}{ The batteries of accumulations } \\
\hline Manufacturer & Power Safe TS \\
\hline Model & TYS-7 \\
\hline Type & $7 \mathrm{OpzS} 700$ \\
\hline Tension by unit & $2 \mathrm{~V}$ \\
\hline Capacity (C10) by unit & $875 \mathrm{Ah}$ \\
\hline
\end{tabular}




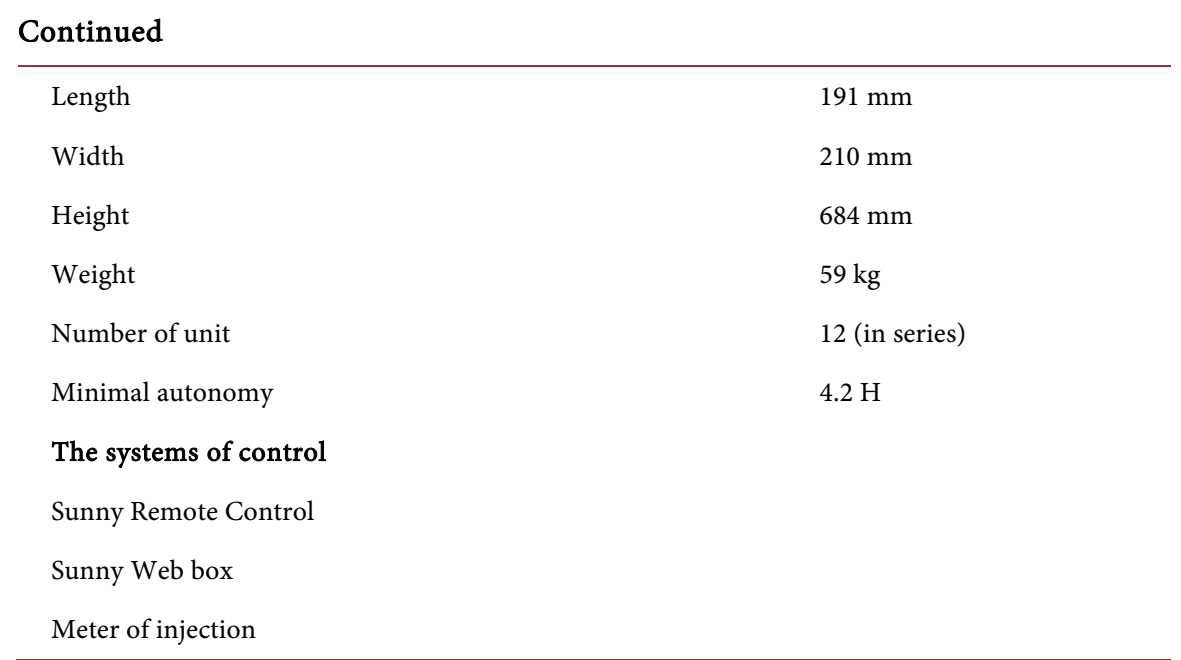

when the network breaks down, the inverter of injection disconnects from the main network. It works in an autonomous way thanks to the inverter backup SBU which also feeds batteries as indicated in Figure 2.

\subsection{Functioning in Mode Injection to the Network}

The security system controls permanently if the tension and the frequency of the public network are in the limits permissible. Batteries are loaded if need be, the big devices can be fed by the network as indicated in Figure 3.

In case of absence or of failure of the network, a physical separation by means of relay assures the galvanic insulation making impossible any injection.

\subsection{Off-Line Functioning's (Backup System)}

In the case of the overtaking the standardized limits or in case of a failure of the main network, the public network is disconnected within $200 \mathrm{~ms}$ and the functioning continues almost continuously as a network in community policing.

If the tension disappears completely, the inverter disconnects from the network within $50 \mathrm{~ms}$. So, if the production PV is lower than the wanted power, the inverter backup SBU brings the difference by taking some energy in batteries of accumulators charged by the system when the production is superior to the wanted power as shown in Figure 4.

\subsection{Systems of Control}

The pilot-system connected to the distribution network of electricity is controlled to estimate and follow its performances. A system of control is used and includes Sunny Remote Control which allows to put into service and to watch easily the remote equipment or with the screen in four lines which gives information onto the current status of the installation in a clear way and all at once the eye [9]. Sunny Sensorbox allows seizing on your installation PV the environmental data important for the supervision of the power. Sunny Webbox is a software which allows to visualize and to manage the data of your installation 


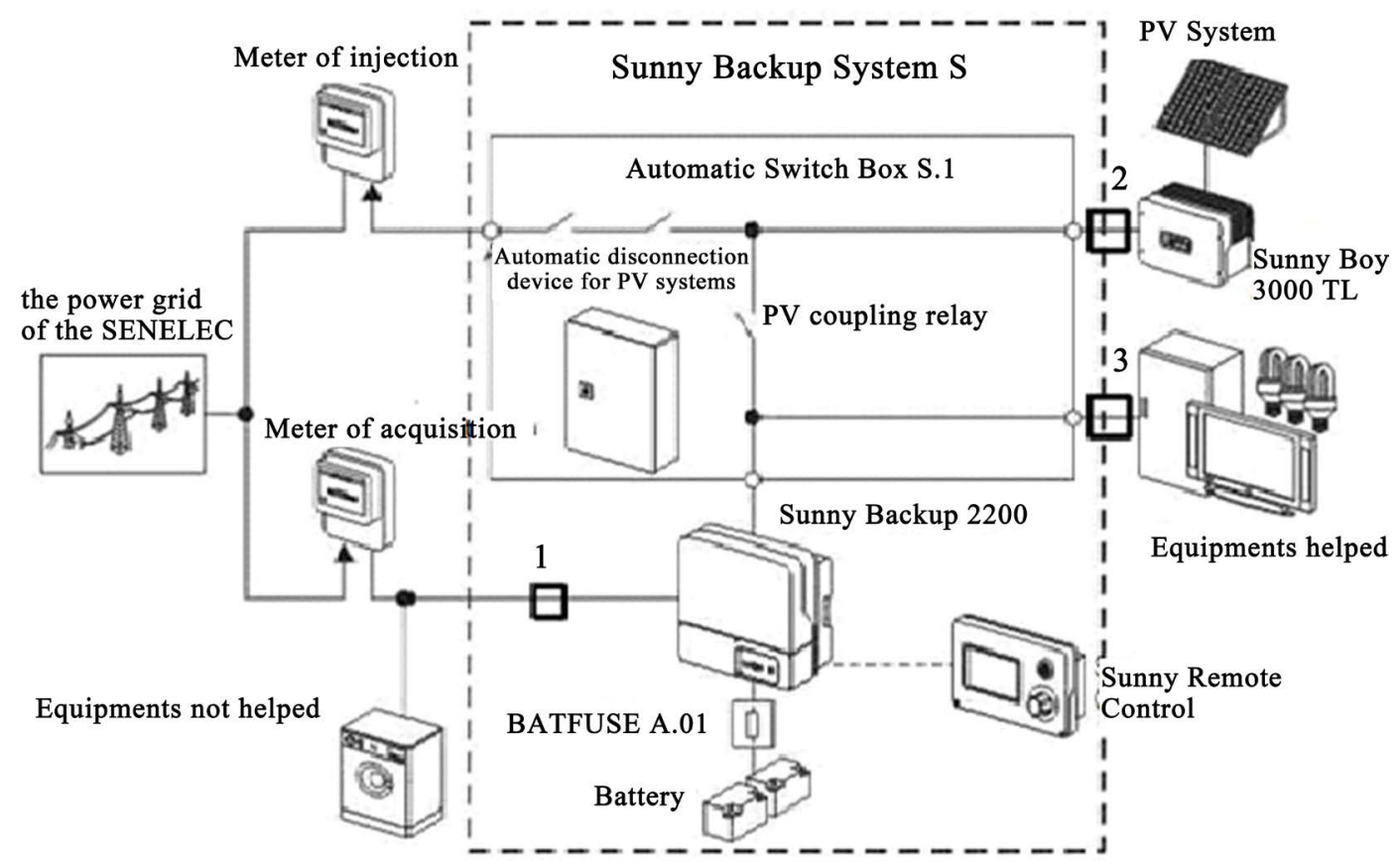

Figure 2. Plan of the installation.

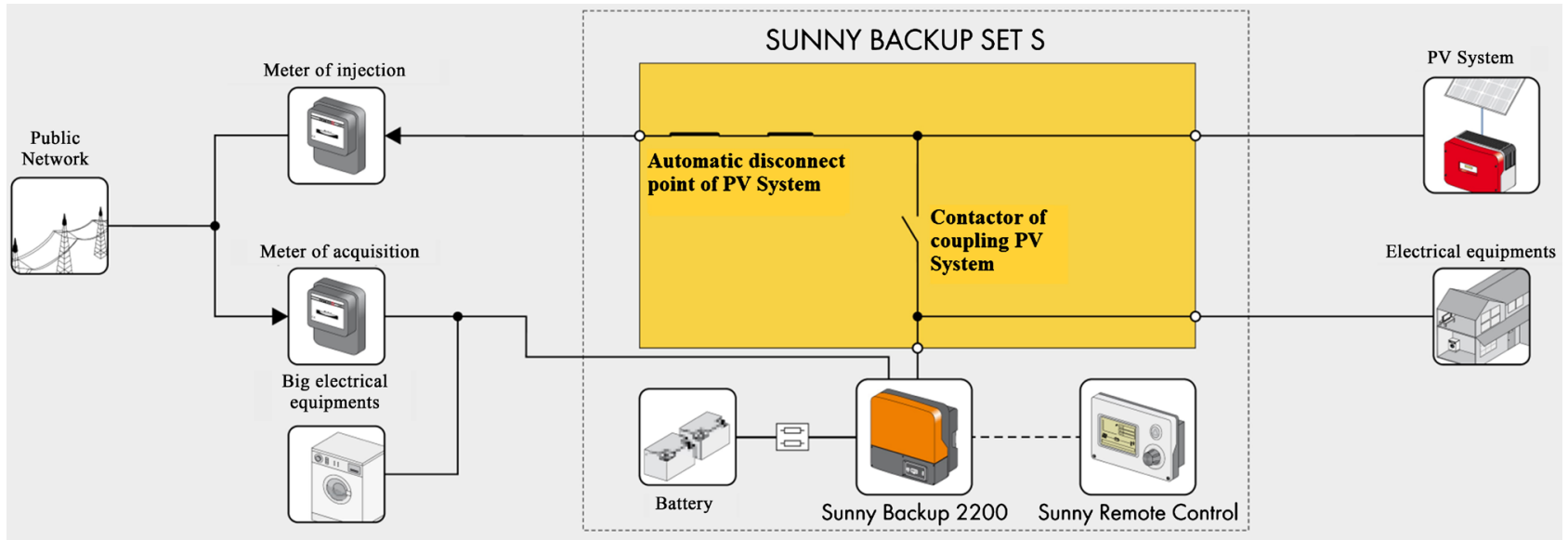

Figure 3. Functioning in injection mode.

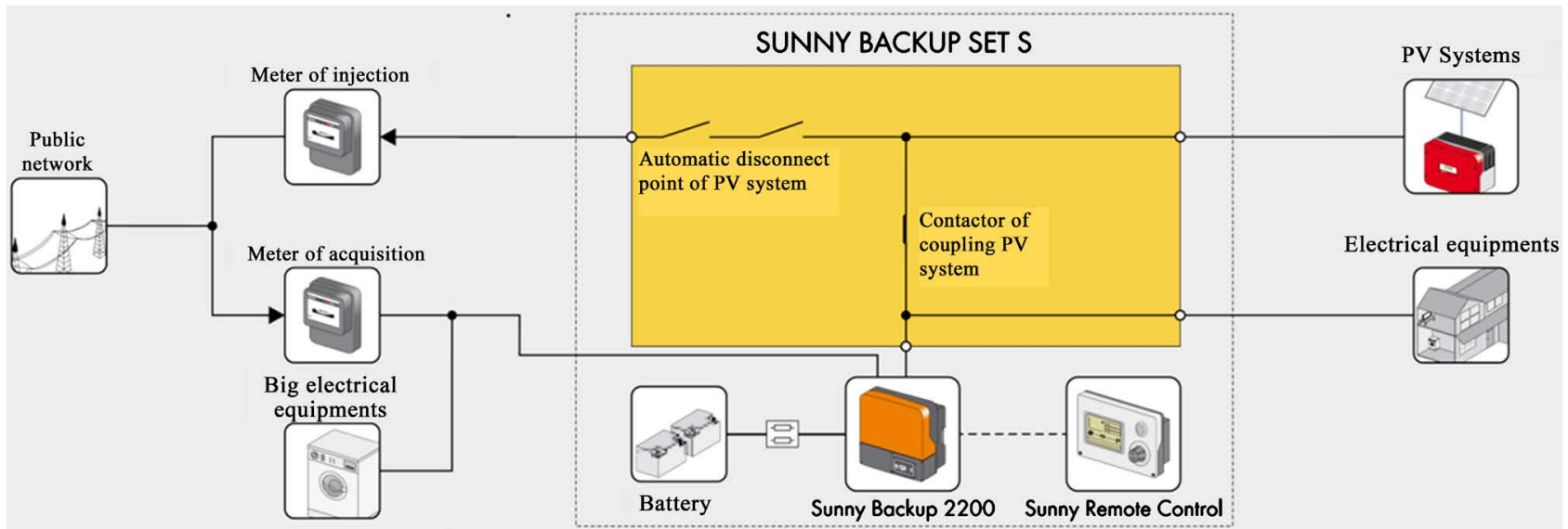

Figure 4. Functioning in autonomous mode. 
Bluetooth or Speed wire on PC. You can also configure individual devices either whole groups of devices of your installation. It also contributes to simplify the configuration of inverters: The absence of cabling accelerates and facilitates the maintenance of the photovoltaic plant [10].

\section{Results of the Performances of the Photovoltaic System}

The monthly and annual follow-up of the installation $3.15 \mathrm{kWc}$ was made to estimate its performances. This was possible by collecting the data and by analysing them to calculate the necessary indications of performance to analyse and interpret the obtained results. To analyse the performances of this system, we used parameters of performance which indicate us the state of our system.

\subsection{Meteorological Data}

In Senegal, we have a seasonal climate where the average speed of the wind is of $5 \mathrm{~m}$. The annual temperature varies of $22^{\circ} \mathrm{C}$ in $28^{\circ} \mathrm{C}$ with an average of maximal diurnal of $23^{\circ} \mathrm{C}$ from January till April and of $24^{\circ} \mathrm{C}$ in May and December. From June till October, the temperatures achieve $28^{\circ} \mathrm{C}$. The site has a climate characterized by two seasons. A rainy season from June till October, with an importance of the precipitation and a dry season from November till May with temperatures included of $22^{\circ} \mathrm{C}$ in $28^{\circ} \mathrm{C}$. We collected during the year 2015 to the daily paper the monthly variation of the sun rays on this site. The obtained results were recapitulated on Figure 5. Of Mars in July we have a strong radiation corresponding to the dry season with a peak in May, then a diminution from August corresponding at the beginning of the wintering then a resumption at the end of this rainy period at about November.

\subsection{Photovoltaic Surface Efficiency}

The surface yield quantifies the conversion of the power of the solar irradiation in electric power of a module or a photovoltaic cell on a surface given to the standards STC [11]. Its calculation bases itself on the solar irradiation:

$$
\text { Yield }=\frac{\text { electric power }\left(\mathrm{W} / \mathrm{m}^{2}\right)}{\text { solar irradiance }\left(\mathrm{W} / \mathrm{m}^{2}\right)}
$$

For this system, having made the characteristic curve I/V for modules as shown in Figure 6, the characteristics were measured to determine the real performances of the generator PV, indicated in Table 2. A comparison was made with the data of the manufacturer to determine the possible gap. But it is necessary to know that the parameters vary per the location, according to the season or still on the outside conditions [11]. From where the necessity of quantifying these variations of yield per the real conditions by the ratio of performance.

\subsection{Ratio of Photovoltaic Performance}

De Cardona et al. [12] defined the ratio of performance as being the report of the 


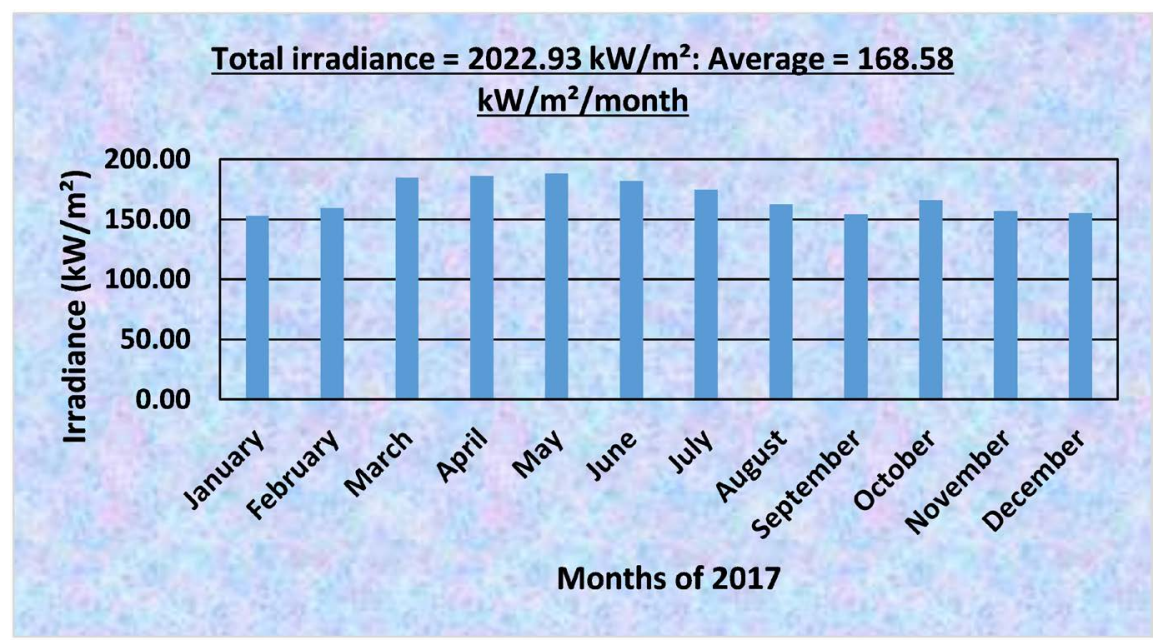

Figure 5. Monthly irradiance of 2017.

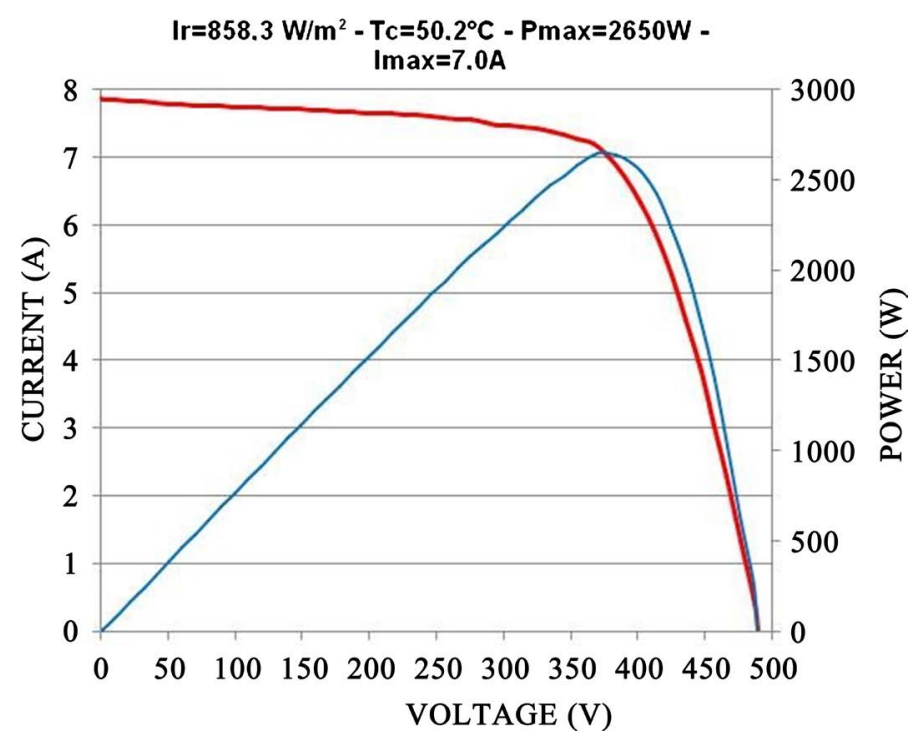

Figure 6. I/V characteristic curve.

Table 2. The real performance of the generator.

\begin{tabular}{ccc}
\hline \multicolumn{3}{c}{ Résumé du test-Conditions STC $\left(1000 \mathrm{~W} / \mathrm{m}^{2}-25^{\circ} \mathrm{C}\right)$} \\
\hline & Power $(\mathrm{Wc})$ & Yield on panels (\%) \\
\hline Data of manufacturer & 3240 & 13.4 \\
Data measured & 3451.42 & 14.86 \\
Gap (\%) & +6.5 & +10.8 \\
\hline
\end{tabular}

final yield on the reference yield. The reference yield was the solar irradiance in the plan of the generator for a moment given divided by the solar irradiance in the standard condition.

The obtained surface yield allows us to have the ratio of performance by making the report between the real yield and the surface yield. It is a measure of the general quality of a photovoltaic plant. He indicates the part of really avail- 
able energy after deduction of the losses of energy (for example heat losses and losses of conductivity) and of the consumption appropriate to the functioning for the food. He is indicated in percentage and indicates the report of producible real on producible theoretical on the conditions STC [13].

$$
\mathrm{PR}=\frac{\text { Real energy efficiency }}{\text { Theoretical energy efficiency }}
$$

The real energy efficiency corresponds to the energy which the photovoltaic plant generated during the year brought reported to the surface of all the modules. During year 2017, this system produced energy of $3721.25 \mathrm{kWh}$, as shown in Figure 7.

$$
R_{\text {real }}=\frac{3394.410}{23.29}=145.75 \mathrm{kWh} / \mathrm{m}^{2}
$$

The energy efficiency in theory possible obtains by making the product of the accumulation of the moderate global values of the radiation and the overall efficiency supplied by the data of the installation (0.1388) [14].

$$
R_{\text {theoretical }}=2022.93 \times 0.1388=280.78 \mathrm{kWh} / \mathrm{m}^{2}
$$

So, he ratio of performance is:

$$
\mathrm{PR}=\frac{159.79}{280.78}=0.569, \quad \mathrm{PR}=56.9 \%
$$

It means that approximately $48 \%$ of the energy shone during the period of observation was not able to be used further to circumstances such as the losses of conductivity, heat losses or for example the defects on components. W We need an inspection more in detail of the installation so as to eliminate impurities of panels PV or replace or repair the defective components.

\subsection{Photovoltaic Specific Efficiency}

The specific yield Yp corresponds to the total energy generated by the photovoltaic plant during year in $\mathrm{kWh}$, returned to the unity of power kilowatt crest [9]. It is connected to the ratio of performance. It is an indicator of profitability of a project and allows determining the ratio of performance if we have knowledge of the irradiation [15].

$$
\text { Yp }=\frac{\text { annual production }}{\text { peak power }}
$$

During year 2017 the system produced an energy of $3721.25 \mathrm{kWh}$. The specific yield is then:

$$
\mathrm{Yp}=\frac{3394.41}{3.15}=1077.59 \mathrm{kWh} / \mathrm{kWc} / \mathrm{an}
$$

\section{Analysis of the Performances}

During the year, the energy produced by the system is $3394.41 \mathrm{kWh}$. This corresponds to an average production of $282.868 \mathrm{kWh}$ a month as indicated in Figure 7. 


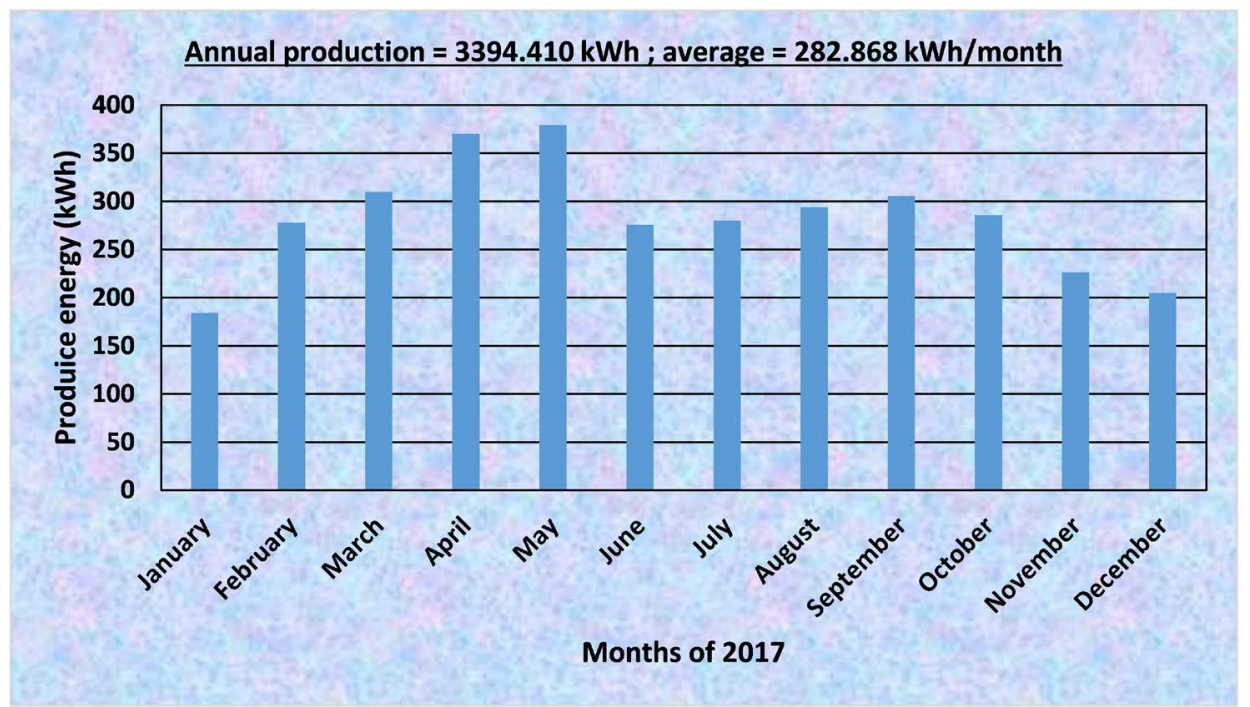

Figure 7. Annual production of the installation.

We notice that the production is strong from March till May and July till October when we are dry at the height of the season with strong irradiations and the raining season with clean modules. Then we note a certain reduction from November till January causes of low monthly brilliance. Then a production which starts again from February till April. This production is decreasing about the production of the previous year (4478.757 kWh either an average of $398.23 \mathrm{kWh}$ a month) and far from its annual average production (5040 kWh or an average of $420 \mathrm{kWh}$ a month). This is partially due by a lot of diverse loss of capture such as the shade of the losses of cabling but especially accumulation of dust due to searches made on the system to raise the level of degradation caused by the dust. The energy injected in the network of the SENELEC is $2504 \mathrm{kWh}$. This corresponds to an average injection of $208.66 \mathrm{kWh}$ a month. The difference of energy, which is the part of energy not injected $(890.41 \mathrm{kWh})$, represents the energy consumed to recharge batteries and possible losses. This instability shows itself especially when the values of the tension or the frequency are situated outside the beach of tension or defined frequency. Beach of frequencies between 47.65 $\mathrm{Hz}$ and $50.5 \mathrm{~Hz}$ and beach of tension between $187 \mathrm{~V}$ and $261.5 \mathrm{~V}$. It is also necessary to note that the CERER is situated at the end of line, which facilitates these unhooking's of the network. There are also some defects of landing which favourites this instability. We also notice one disjunction frequents at the level of the point of injection. In this case falling, the operation being manual, it is necessary to reengage the circuit breaker to boost the injection. Otherwise, they are hours or a whole day of loss of production. The meteorological data show to us that this year was relatively hot what reduced considerably the yield on cells. This renewal of heat can give some explanation by climate change noted almost everywhere in the world. This reduction in the yield on cells pulled the reduction in the real yield from where that of the ratio of performance globally.

The monthly ratio of performance indicated in Figure 8 show that it is different 


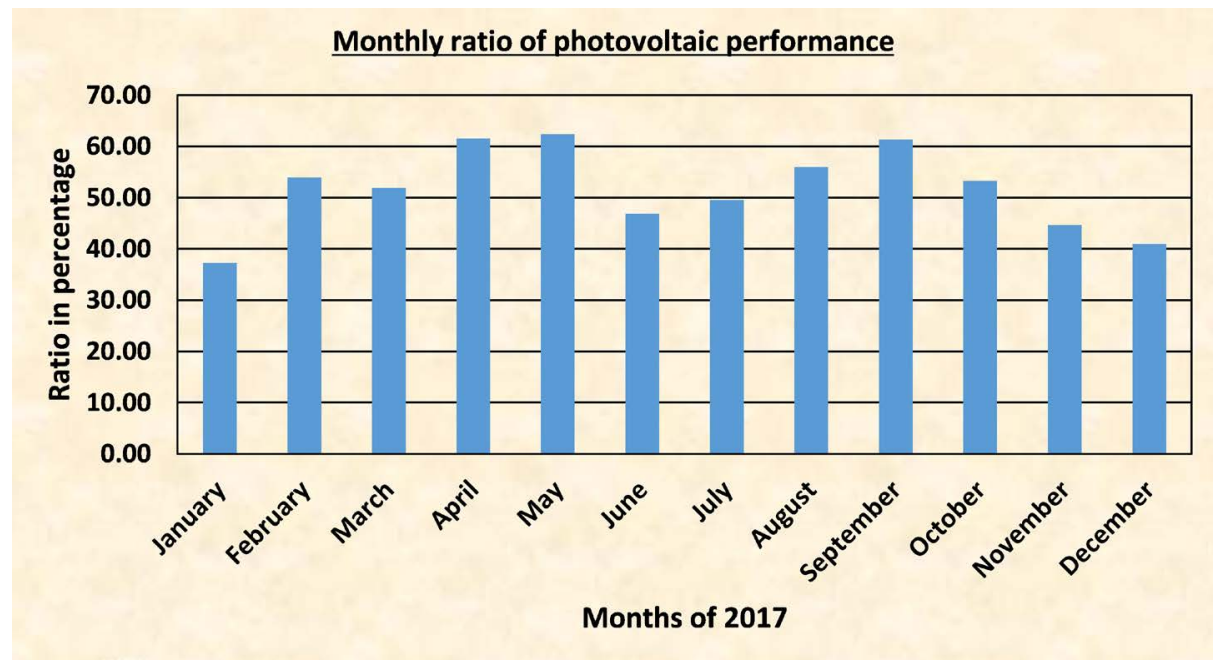

Figure 8. Monthly ratio of photovoltaic performance.

between the months. But we saw that this strong irradiation had positive effects on the production of the months as March, in April and May with strong power productions. This system, even with a reduced production, has an educational utility but also a long lasting of lives of 25 years. The estimation of the energy generated by this installation corresponds to the consumption of electricity of 25 people, an annual economy of oil: $352 \mathrm{~kg}$ that is atmospheric 414 litters, the annual reduction of pollutant emission of:

- $3269 \mathrm{~kg}$ of $\mathrm{CO}_{2}$

- $24 \mathrm{~kg}$ of $\mathrm{SO}_{\mathrm{x}}$

- $9 \mathrm{~kg}$ of $\mathrm{NO}_{\mathrm{x}}$

- $0.5 \mathrm{~kg}$ of $\mathrm{CO}$

\section{Conclusion}

The analysis of the performances of the first photovoltaic system connected to the network of Senegal, presented in this article, shows us that the follow-up of the performances is very important for the systems connected to the network. This pilot system connected to the network has enabled SENELEC to have the first system connected to the network and to make it a way to test the feasibility of injecting to the network in Senegal. The indications of performances such as the surface efficiency, the ratio of performance as well as specific efficiency showed us that the losses of capture as well as the climate change had effect to reduce the annual production compared with the previous year and compared with its average annual production. But this is not the case for every month. So, we note of strong production during the dry season and a production which decreases during rainy season. The design of the system allowed us to save energy used by the rescued loads when the grid was not in optimal conditions to receive the energy produced. But, these performances do not depend completely on its size or on its defects of the system, they depend mainly on weather conditions of the zone. Production losses have shown us that performance also depends on the 
stability of the network. The performance ratio showed us that much of the energy radiated during the observation period could not be used due to circumstances such as conductivity losses, thermal losses or, for example, defects on components. However, a technical analysis is in progress to estimate the necessity of a system of more successful follow-up on-the-spot and remote 24 hours a day, which could significantly increase specific performance. This pilot system shows us that the monthly energy production of the PV system would cover the monthly energy requirements of an average of 2.87 households.

\section{Acknowledgements}

We present our sincere thanks to all the staff of the Center of Studies and Researches on the Renewable Energies (CERER) for their availability and the opening which they showed. We also thank the Laboratory of the Semiconductor and Solar Energy (LASES) of the University Cheikh Anta Diop of Dakar for the supplied information and the very beneficial exchanges.

\section{Conflicts of Interest}

The authors declare no conflicts of interest regarding the publication of this paper.

\section{References}

[1] Lam, K.H., Lai, T.M., Lo, W.C. and To, W.M. (2012) The Application of Dynamic Modelling to the Grid-Connected PV (Photovoltaic) Systems. Energy, 46, 264-274. https://doi.org/10.1016/j.energy.2012.08.023

[2] Santiago, S., Aissa, C. and Engin, K. (2013) Automatic Fault Detection in Grid Connected PV Systems. Solar Energy, 94, 119-127. https://doi.org/10.1016/j.solener.2013.05.001

[3] Aristobal, A.J. and Gordillo, G. (2008) Performance Monitoring Results of the First Grid-Connected BIPV System in Colombia. Renewable Energy, 33, 2475-2484. https://doi.org/10.1016/j.renene.2008.01.018

[4] Hoz, J.D.L., Boix, O., Martin, H., Martin, B. and Graells, M. (2010) Promotion of Grid-Connected Photovoltaic System in Spain: Performance Analysis of the Period 1998-2008. Renewable and Sustainable Energy Reviews, 14, 2547-2563. https://doi.org/10.1016/j.rser.2010.07.059

[5] Jannuzzi, G.D.M. and Melo, C.A.D. (2013) Grid-Connected Photovoltaic in Brasil: Policies and Potential Impacts for 2030. Energy for Sustainable Development, 17, 40-45. https://doi.org/10.1016/j.esd.2012.10.010

[6] Sidi, C.E.B.E., Ndiaye, M.L., Bah, M.E., Mbodj, A., Ndiaye, A. and Ndiaye, P.A. (2016) Performance Analysis of the First Large-Scale (15 MWp) Grid-Connected Photovoltaic Plant in Mauritania. Energy Conversion and Management, 119, 411-421. https://doi.org/10.1016/j.enconman.2016.04.070

[7] Loi n 98-29 du 14 avril 1998 relative au secteur de l'électricité.

[8] Loi n 2010-21 portant loi d'orientation sur les énergies renouvelables.

[9] https://www.sma.de/fr/produits/onduleurs-a-batterie

[10] http://www.sma.de/fr/produits/surveillance-controle/sunny-explorer.html 
[11] System of grid-L'expertise des solutions Energetiques Durable-Photovoltaïque: Les indicateurs de rendement et de performance-Décembre 2012.

[12] De Condona, S. and Lopez, L. (1999) A General Multivariate Qualitative Model for Sizin Stand alone Photovoltaic Systems. Solar Energy Materials \& Solar Cells, 59, 185-197. https://doi.org/10.1016/S0927-0248(99)00020-3

[13] Solutions photovoltaïques autonomes-Anne Labouret-25 novembre 2010.

[14] Labouret, A. and Villoz, M. (2006) Energie Solaire Photovoltaïque. $3^{\text {ème }}$ Edition, Dunod, Paris.

[15] Systèmes photovoltaïque raccordés au réseau. Guide de rédaction de cahier de charges. Techniques de consultation à destination des maîtres d'ouvrages. ADEME Version 2007. 